\title{
Assessment of the Abbreviated National Eye Institute Visual Function Questionnaire (NEI VFQ 9) in blepharoptosis and dermatochalasis
}

\author{
Avaliação do Questionário Abreviado de Função Visual do National Eye Institute (NEI VFQ 9) \\ em blefaroptose e dermatocálase
}

César A. Briceño ${ }^{1}$, Molly L. Fuller², Elizabeth A. Bradley ${ }^{3}$, Christine C. Nelson ${ }^{1}$

\begin{abstract}
Purpose: To evaluate the Abbreviated National Eye Institute Visual Function Questionnaire (NEIVFQ 9), which is shorter than those previously published, as a tool for assessing vision-related quality of life in patients with ptosis and dermatochalasis. Methods: This is a cohort study of 46 patients who underwent blepharoptosis and/or upper eyelid blepharoplasty surgery by a single surgeon (CN) in 2013 in a public, academic, ambulatory care referral center. Patients included 29 who underwent blepharoplasty, 11 who underwent ptosis surgery, and 6 who underwent combined surgery. The NEI-VFQ 9 was administered pre- and postoperatively, and the composite scores were compared using Student's t-test. Survey duration was timed in a subset of patients. The hypothesis was that the NEI VFQ 9 could detect a statistically significant improvement in composite score after surgical intervention.

Results: The mean pre- and postoperative NEI VFQ 9 composite scores were 74.9 and 86.8, respectively, in the blepharoplasty-only group $(P<0.0001), 72.07$ and 86.41, respectively, in the ptosis-only group $(P=0.004)$, and 75.8 and 87.2 , respectively, in the combined group ( $P=0.022)$. There was no correlation between the gain in composite score and the change in upper eyelid margin to reflex distance. Twenty-five patients were timed filling out the survey, and the mean was 2.3 min. Conclusions: The NEI VFQ 9 consistently demonstrates a significant increase in visual function for blepharoptosis and dermatochalasis patients. Thus, it may be a useful tool for assessing vision-related quality of life in patients with ptosis and dermatochalasis.
\end{abstract}

Keywords: National Eye Institute (U.S.); Blepharoptosis; Eyelids; Disability evaluation; Quality of life; Visual acuity

\section{RESUMO}

Objetivo: Avaliar o Questionário Abreviado de Função Visual do National Eye Institute (NEI VFQ 9) como uma ferramenta para avaliar a visão relacionada com a qualidade de vida (QoL) em pacientes com blefaroptose e dermatocálase.

Método: Estudo de coorte de blefaroptose e dermatocálase pacientes tratados por um único cirurgião (CN) em 2013. O acompanhamento foi de 2-3 meses. Pacientes em um centro de referência acadêmico para a atenção pública ambulatorial com ptose funcional e/ou dermatocálase de pálpebra superior foram avaliados prospectivamente utilizando o NEI-VFQ 9. Quarenta e seis pacientes completaram o estudo: 29 pacientes se submeteram somente à blefaroplastia, 11 apenas à cirurgia de ptose, e 6 pacientes à cirurgia combinada. Foram excluídos pacientes com outra cirurgia simultânea da pálpebra. O teste foi repetido em uma visita pós-operatória. A duração teste foi cronometrada em um subgrupo de pacientes. Escores compostos prée pós-operatórios foram comparados com o teste T de Student. O desfecho principal foi a pontuação composta. Os autores propõem que a NEI VFQ 9 seria capaz de detectar uma melhora estatisticamente significativa na pontuação composta após a intervenção cirúrgica.

Resultados: No grupo de blefaroplastia apenas, o NEI VFQ 9 apresentou a média composta de 74,9 e 86,8 no pré e pós-operatório, respectivamente ( $p<0,0001)$. Para os pacientes submetidos apenas à cirurgia de ptose, a pontuação média composta foi 72,07 e 86,41, no pré e pós-operatório, respectivamente $(p=0,004)$. No grupo de cirurgias combinadas combinação, a pontuação composta média pré-operatória foi de 75,8, e a pós-operatória foi de 87,2 ( $(p=0,022)$. Não houve correlação entre o ganho de pontuação composta e a mudança no MRD1. Vinte e cinco pacientes foram cronometrados ao preencher o teste, a média foi de 2,3 minutos.

Conclusões: O NEI VFQ 9 demonstra consistentemente um aumento na função visual para pacientes submetidos à cirurgia de blefaroptose e dermatocálase, sendo um instrumento de pesquisa mais curto do que daqueles publicados anteriormente.

Descritores: National Eye Institute (U.S.); Blefaroptose; Pálpebras; Avaliação da deficiência; Qualidade de vida; Acuidade visual

\section{INTRODUCTION}

Quality of life (QoL) measurements in oculoplastic surgery are becoming increasingly relevant, given the evolving healthcare and payer systems in the United States. Several instruments have been used to measure QoL outcomes in ptosis repair and upper blepharoplasty. They consistently demonstrate that these surgical interventions have a real and measureable positive impact on vision-related QoL ${ }^{(1-4)}$. The previously employed instruments have ranged from published ophthalmic QoL instruments, such as the NEI-VFQ-25(1), to specifically designed ptosis and dermatochalasis instruments adapted from other QoL instruments ${ }^{(2-4)}$. No prior study has timed the patients as they complete these questionnaires, which range in length from 25 to 36 items. The NEI-VFQ-25, which is one of the most commonly used ophthalmic QoL instruments, has been vetted in a number of conditions, including cataract, glaucoma, and age-related macular degeneration ${ }^{(5-12)}$. Asano and Osaki demonstrated that it is also sensitive

Submitted for publication: January 27, 2016

Accepted for publication: March 16, 2016

Department of Ophthalmology, Kellogg Eye Center, University of Michigan, Ann Arbor, Michigan, USA.

Department of Ophthalmology, Wake Forest School of Medicine, Winston-Salem, North Carolina, USA.

Department of Ophthalmology, Mayo Clinic, Rochester, Minnesota, USA.

Funding: No specific financial support was available for this study.

Disclosure of potential conflicts of interest: None of the authors have any potential conflict of interest to disclose.

Corresponding author: César A. Briceño. Eye Plastic, Orbital and Facial Cosmetic Surgery Service. W.K. Kellogg Eye Center, University of Michigan - 1.000 Wall Street. Ann Arbor, MI 48105 - USA E-mail: cesarb@med.umich.edu

Approved by the following research ethics committee: University of Michigan (\# 2001-0324). 
in detecting improvements in QoL after ptosis surgery ${ }^{(1)}$. Kodjebacheva et al. published shortened versions of the survey, including the VFQ-9, which proved to be comparable to the 25-item version across a number of eye conditions. The vision-related functional domains tested in the NEI-VFQ-9 are as follows: general vision, near vision, distance vision, driving, peripheral vision, role limitation, and mental health ${ }^{(9)}$. This is the first study designed to assess whether the shortened VFQ-9 is sensitive enough for assessing vision-related QoL in patients with ptosis and dermatochalasis.

\section{METHODS}

Sixty-eight subjects were recruited for the study. The inclusion criteria included age older than 18 years, diagnosis of acquired involutional blepharoptosis and/or dermatochalasis at initial visit, best corrected Snellen visual acuity of 20/40 or better in each eye, and the ability to complete written preoperative and postoperative questionnaires. The exclusion criteria included failure to complete the second survey and any other simultaneous eyelid procedure at the time of surgery, such as lower eyelid blepharoplasty, brow lift or browpexy, biopsy of any lesions, or eyelid tightening. Five patients were excluded on the basis of simultaneous surgery, and 17 did not complete a second survey.

In the end, 46 patients with blepharoptosis and/or upper eyelid dermatochalasis who underwent blepharoptosis and/or upper eyelid blepharoplasty surgery by a single surgeon $(\mathrm{CN})$ met the study criteria and were evaluated in the study. The upper eyelid margin to reflex distance (MRD1) was measured pre- and postoperatively in ptosis patients, using a millimeter ruler, to the nearest $0.5 \mathrm{~mm}$. Dermatochalasis was diagnosed based on the presence of visible hooding of the upper eyelid at rest with a neutral facial expression. The study was verbally explained to each patient, and verbal consent was obtained from each participant. An Institutional Review Board (IRB) waiver of written informed consent was obtained. All manipulation of health information was conducted in compliance with the regulations of the Health Insurance Portability and Accountability Act, as required by the University of Michigan.

The NEI-VFQ 9 was administered in the clinic during the initial visit. It was then repeated at the 2-3 month postoperative visit. The complete NEI-VFQ-9 described by Kodjebacheva et al. is reproduced in table 1. Composite scores were calculated from the preoperative and postoperative questionnaires. Ptosis only, blepharoplasty only,

Table 1. Nine-item national eye institute visual function questionnaire (NEI-VFQ-9)

\begin{tabular}{|c|c|c|}
\hline \multicolumn{3}{|c|}{ Q1. General vision (6-level) } \\
\hline \multicolumn{3}{|c|}{ At the present time, would you say your eyesight (with glasses or contact lenses, if you wear them) is: } \\
\hline 4) Poor & 5) Very poor & 6) Are you completely blind? \\
\hline \multicolumn{3}{|c|}{ How much of the time do you worry about your eyesight? } \\
\hline 1) None of the time & 2) A little of the time & 3) Some of the time \\
\hline 4) Most of the time & 5) All of the time & \\
\hline 1) No difficulty at all & 2) A little difficulty & 3) Moderate difficulty \\
\hline 4) Extreme difficulty & 5) Stopped doing this because of your eyesight & 6) Stopped doing this for other reasons or not interested in doing this \\
\hline
\end{tabular}

Q4. Near vision, seeing well up close (6-level)

How much difficulty do you have performing work or hobbies that require you to see well up close, such as cooking, sewing, fixing things around the house, or using hand tools?

1) No difficulty at all

$\begin{array}{lll}\text { 2) A little difficulty } & \text { 3) Moderate difficulty }\end{array}$

4) Extreme difficulty

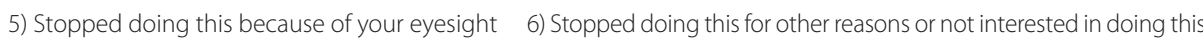

Q5. Distance vision, going down stairs at night (6-level)

Because of your eyesight, how much difficulty do you have going down steps, stairs, or curbs in dim light or at night?

1) No difficulty at all

2) A little difficulty

3) Moderate difficulty

4) Extreme difficulty

5) Stopped doing this because of your eyesight

6) Stopped doing this for other reasons or not interested in doing this.

Q6. Driving (6-level)*

How much difficulty do you have driving during the daytime in familiar places?

2) A little difficulty

3) Moderate difficulty

4) Extreme difficulty stopped doing this because of $\quad$ 5) Stopped doing this for other reasons or not your eyesight interested in doing this

Q7. Role limitation (5-level)

Are you limited in how long you can walk or perform other activities such as housework, child care, school, or community activities because of your vision?
1) All of the time,
2) Most of the time
3) Some of the time,
4) A little of the time
5) None of the time

Q8. Peripheral vision (6-level)

Because of your eyesight, how much difficulty do you have noticing objects off to the side while you are walking along?

$\begin{array}{lll}\text { 1) No difficulty at all } & \text { 2) A little difficulty } & \text { 3) Moderate difficulty }\end{array}$

4) Extreme difficulty $\quad$ 5) Stopped doing this because of your eyesight

6) Stopped doing this for other reasons or not interested in doing this

Q9. Near vision, finding objects on a crowded shelf (6-level)

Because of your eyesight, how much difficulty do you have finding something on a crowded shelf?

1) No difficulty at all

2) A little difficulty

3) Moderate difficulty

4) Extreme difficulty

5) Stopped doing this because of your eyesight

6) Stopped doing this for other reasons or not interested in doing this. 
and combined surgery patients were analyzed separately. The mean preoperative and postoperative scores were calculated and compared using a paired t-test. All statistics were calculated using the Statistical Package for the Social Sciences (SPSS) software (IBM). Changes in composite scores were compared to those obtained by Asano and Osaki ${ }^{(1)}$ in their blepharoptosis patients as a benchmark.

Twenty-five consecutive participants were timed as they filled out the questionnaire to determine the average amount of time required to complete the survey. The task of timing the patients was disruptive to technician and clinic flow; thus, timing was only performed on this sequential subset.

\section{RESULTS}

The study included 46 subjects (14 men and 32 women) who underwent surgery for blepharoptosis $(n=29)$, upper eyelid dermatochalasis $(n=11)$, or both $(n=6)$. The mean age at baseline was $68 \pm$ 8.1 years. All subjects were followed for 2-3 months.

The mean pre-and postoperative NEI VFQ 9 composite scores are presented in table 2 . The composite scores increased significantly for each group of patients. In the blepharoplasty-only group $(n=29)$, every item in the questionnaire had a statistically significant increase in score when using a paired t-test, except the question about role limitation (question 7). In the ptosis-only group $(n=11)$, the three domains driving the increase in composite score were near vision and distance vision (questions 3-5). In the combination group, near vision and peripheral vision (questions 3, 8, and 9) were the main drivers of the increase in composite score.

Twenty-five sequential patients were timed filling out the survey, and the mean was $2.3 \pm 1.9 \mathrm{~min}$.

\section{DISCUSSION}

We sought to determine whether the NEI-VFQ 9 is a useful tool for detecting improvements in vision-related QoL in patients undergoing ptosis surgery and/or upper eyelid blepharoplasty, compared with published data on longer survey instruments. Our results have indicated that statistically significant improvements can indeed be seen in these patients' NEI-VFQ 9 composite scores. Furthermore, the scores obtained in our sample are similar to those reported by Asano and Osaki ${ }^{(1)}$ using the longer NEI-VFQ-25 in ptosis surgery patients. They reported a mean increase in composite score from 74 to 81 after ptosis surgery, which is similar to the results obtained in this study. We have seen improvements across most domains tested in the VFQ-9 in our blepharoplasty-only group. The other groups showed statistically significant improvements in fewer domains, while maintaining a significant improvement in their composite scores. Given the modest number of participants in this group, it is possible that the other domains

Table 2. Composite score of survey results

\begin{tabular}{lcccc}
\hline Group & n & Pre-op & Post-op & p-value \\
\hline Blepharoplasty surgery only & 29 & 74.9 & 86.8 & $<0.0001$ \\
Ptosis surgery only & 11 & 72.1 & 86.4 & 0.0040 \\
Blepharoplasty and ptosis surgery & 6 & 75.8 & 87.2 & 0.0220 \\
\hline
\end{tabular}

were underpowered to show significance. Role limitation is the only subdomain that did not show a statistically significant improvement in composite score in the blepharoplasty group. The mean preoperative score in this question was 86 , and our findings possibly reflect a ceiling effect.

Health-related QoL outcomes are becoming increasingly important in determining the allocation of healthcare resources, and understanding these outcomes allows us to better inform patients. The vision-related QoL benefits of blepharoptosis surgery have been extensively documented ${ }^{(2,3,13,14)}$. The impact of upper blepharoplasty surgery has also been demonstrated, though in fewer studies ${ }^{(4,14)}$. The authors believe that the pressure to demonstrate measurable increases in QoL as a result of oculoplastic interventions will only intensify, and we need time-efficient, short survey instruments to accurately perform assessments.

This is the first study to use one of the NEI-VFQ instruments in ptosis and dermatochalasis in North America and the first to utilize this abbreviated version of the questionnaire in oculoplastics. Despite its brevity, the nine-item NEI-VFQ-9 is able to capture vision-related QoL changes in patients with blepharoptosis and dermatochalasis.

\section{REFERENCES}

1. Asano ME, Osaki MH. [Quality of life assessment in patients with blepharoptosis]. Arq Bras Oftalmol. 2006;69(4):545-9.Portuguese.

2. Battu VK, Meyer DR, Wobig JL. Improvement in subjective visual function and quality of life outcome measures after blepharoptosis surgery. Am J Ophthalmol. 1996;121(6): 677-86.

3. Federici TJ, Meyer DR, Lininger LL. Correlation of the vision-related functional impairment associated with blepharoptosis and the impact of blepharoptosis surgery. Ophthalmology. 1999;106(9):1705-12.

4. Sanchez-Castellanos A, Nelson CC, Musch D. Impact of Lid position surgery on socia and emotional aspects of quality of life in adults. In: American Society of Ophthalmic Plastic and Reconstructive Surgeons Fall Symposium; 2010 Oct 13-14; Chicago, IL.

5. Bradley EA, Sloan JA, Novotny PJ, Garrity JA, Woog JJ, West SK. Evaluation of the National Eye Institute visual function questionnaire in Graves' ophthalmopathy. Ophthalmology. 2006; 113(8):1450-4. Comment in: Ophthalmology. 2007;114(7): 1416-7; author reply 1417-8.

6. Clemons TE, Chew EY, Bressler SB, McBee W; Age-Related Eye Disease Study Research Group. National Eye Institute Visual Function Questionnaire in the Age-Related Eye Disease Study (AREDS): AREDS Report No. 10. Arch Ophthalmol. 2003;121(2):211-7.

7. Cole SR, Beck RW, Moke PS, Gal RL, Long DT. The National Eye Institute Visual Function Questionnaire: experience of the ONTT. Optic Neuritis Treatment Trial. Invest Ophthalmol Vis Sci. 2000:41(5):1017-21.

8. Khadka J, McAlinden C, Pesudovs K. Validation of the National Eye Institute Visua Function Questionnaire-25 (NEI VFQ-25) in age-related macular degeneration. Invest Ophthalmol Vis Sci. 2012;53(3):1276. Comment in: Invest Ophthalmol Vis Sci. 2011; 52(6):3354-9.

9. Kodjebacheva G, Coleman AL, Ensrud KE, Cauley JA, Yu F, Stone KL, et al. Reliability and validity of abbreviated surveys derived from the National Eye Institute Visual Function Questionnaire: the study of osteoporotic fractures. Am J Ophthalmol. 2010; 149(2):330-40

10. Lindblad AS, Clemons TE. Responsiveness of the National Eye Institute Visual Function Questionnaire to progression to advanced age-related macular degeneration, vision loss, and lens opacity: AREDS Report no. 14. Arch Ophthalmol. 2005;123(9):1207-14.

11. Nassiri N, Mehravaran S, Nouri-Mahdavi K, Coleman AL. National Eye Institute Visual Function Questionnaire: usefulness in glaucoma. Optom Vis Sci. 2013;90(8):745-753.

12. Revicki DA, Rentz AM, Harnam N, Thomas VS, Lanzetta P. Reliability and validity of the National Eye Institute Visual Function Questionnaire-25 in patients with age-related macular degeneration. Invest Ophthalmol Vis Sci. 2010;51(2):712-7.

13. Smith HB, Jyothi SB, Mahroo OA, Sharms PN, Sira M, Dey S, et al. Patient-reported benefit from oculoplastic surgery. Eye (Lond). 2012;26(11):1418-23.

14. Warwar RE, Bullock JD, Markert RJ, Marciniszyn SL, Bienenfeld DG. Social implications of blepharoptosis and dermatochalasis. Ophthal Plast Reconstr Surg. 2001;17(4):234-40. 